\title{
Arrest of Afferent Axon Extension by Target Neurons In Vitro Is Regulated by the NMDA Receptor
}

\author{
Douglas H. Baird, ${ }^{1}$ Ekkhart Trenkner, ${ }^{2}$ and Carol A. Mason ${ }^{3}$ \\ ${ }^{1}$ Department of Neurobiology and Anatomy, Medical College of Pennsylvania and Hahnemann University, Philadelphia, \\ Pennsyivania 19129, 2/nstitute for Basic Research in Developmental Disabilities, Staten Island, New York 10314, and \\ 3Departments of Pathology, Anatomy, and Cell Biology, and the Center for Neurobiology and Behavior, College of \\ Physicians and Surgeons of Columbia University, New York, New York 10032
}

Cerebellar granule neurons in vitro specifically arrest the extension of their appropriate presynaptic axons, mossy fibers. This "stop-growing signal" may be an essential step in the formation and specificity of synapses. Here, we have tested whether ionotropic glutamate receptors are involved in the stop-growing signal. When explants of basilar pontine nuclei, a mossy fiber source, were cultured on granule neurons, most pontine neurites terminated $<200 \mu \mathrm{m}$ from their explant of origin, a criterion for the stop-growing signal. In contrast, treatment with the NMDA antagonist $D(-)-2$-amino-5-phosphonopentanoic acid (D-AP5) greatly increased the number of pontine neurites extending beyond $300 \mu \mathrm{m}$, whereas treatment with NMDA reduced the number of pontine neurites extending beyond 200 $\mu \mathrm{m}$. A non-NMDA agonist (AMPA) and antagonist (6-cyano-7- nitroquinoxaline-2,3-dione) did not alter pontine neurite lengths. None of these agents affected neurite outgrowth from pontine explants in the absence of granule neurons, nor did any agent affect the survival of granule neurons. These results indicate that NMDA and D-AP5 specifically perturb an interaction between axons and target cells necessary for the stopgrowing signal, and that NMDA receptors are critical for the development of a major cerebellar afferent system. These findings also suggest that NMDA-sensitive refinement of axon arbors during later development may involve the direct regulation of axon extension by target neurons.

Key words: cerebellum; granule cell; mossy fiber; NMDA receptor; basilar pontine nuclei; axon extension
Axons are highly specific in their innervation of targets, and this specificity manifests itself on several levels. First, axons from a given source innervate specific regions or layers in their target, e.g., in the optic tectum (Yamagata and Sanes, 1995). Second, axons are highly specific in the type of target cell with which they will synapse. For example, mossy fibers synapse with granule neurons of the cerebellar cortex and project into the Purkinje cell or molecular layers only transiently during development (Mason and Gregory, 1984), or when there are ectopic granule neurons in these locations (a rare occurrence) (Palay and Chan-Palay, 1974).

Although the specificity of axonal projections has been well documented, the mechanisms that control axonal growth during termination in specific cell layers and on specific cell types remain obscure. To understand more precisely how target cells regulate the growth of appropriate afferents, we developed an in vitro system based on purified cerebellar target neurons (Baird et al., 1992b). Neurite extension from explants of basilar pontine nuclei, a source of mossy fibers, is arrested by granule neurons, their appropriate target cell. This behavior is considered to be medi-

\footnotetext{
Received Oct. 25, 1995; revised Jan. 25, 1996; accepted Jan. 29, 1996.

This work was supported by a National Research Service Award Fellowship, funds from the Medical College of Pennsylvania, National Institute of Neurological Disorders and Stroke Grants NS33214 (D.H.B.) and NS16951 (C.A.M.), and a National Science Foundation Grant (E.T.). Expert technical assistance was provided by Barbara I ewandowska-Kruk and Rich Blazeski. We thank Carl I agenaur, Iniversity of Pittsburgh, for his gift of the M6 monoclonal antibody. We gratefully acknowledge Amy MacDermott at Columbia University for thoughtful advice and support, and Donald Faber of the Medical College of Pennsylvania and Hahnemann University for insightful comments on this manuscript.

Correspondence should be addressed to Douglas H. Baird, Department of Neurobiology and Anatomy, Medical College of Pennsylvania and Hahnemann University, 3200 Henry Avenue, Philadelphia, PA 19129.

Copyright (C) 1996 Society for Neuroscience $0270-6474 / 96 / 162642-07 \$ 05.00 / 0$
}

ated by a "stop-growing signal" presented by target granule neurons to which mossy fibers respond specifically, as granule neurons do not inhibit the extension of axons from explants of retina, or inferior olivary nuclei (Baird et al., 1992a), a source of ccrcbellar climbing fibers. The stop-growing signal therefore may lead to the arrest of neurite elongation in the internal granule layer and not in other layers of the cerebellar cortex and also may contribute to the conversion of mossy fiber growth cones into mature synaptic terminations.

We have begun to determine which types of molecules comprise the stop-growing signal. Neurotransmitters are a class of molecules that could contribute to target cell selection by growth cones because they are cell- and system-specific and are also known to arrest axon elongation in vitro (Kater and Mills, 1991). Further, growth cones can release transmitters before they contact targets (Hume et al., 1983; Young and Poo, 1983), which would allow differences in growth-cone transmitter type and target cell receptor type to contribute to the regulation of axonal growth by specific target cells during their first contacts.

In this study, we have tested whether ionotropic glutamate receptors, which include NMDA receptors, are involved in the stop-growing signal presented to mossy fibers by cerebellar granule neurons. This class of receptors was selected because granule neurons are glutamatergic and express a profile of NMDA receptor subunits that differs from other cells of the cerebellum (Audinat et al., 1994; Moyner et al., 1994). In addition, neurotransmitters can affect the rate of axon extension by altering intracellular calcium levels in the growth cone (Kater and Mills, 1991), and the NMDA receptor is known to gate calcium currents (Mayer et al., 1987). 


\section{MATERIALS AND METHODS}

Tissue culture. Granule neurons were purified from dissociated cerebellar cells from postnatal day 5-7 rats, as described (Baird et al., 1992a,b), and plated in Lablek chamber slides (NUNC, Naperville, IL) coated first with 0.5 $\mathrm{mg} / \mathrm{ml}$ poly-D-lysine (Sigma, St. Louis, MO), then with $20 \mu \mathrm{g} / \mathrm{ml}$ laminin (Gibco, Grand Island, NY). Granule neurons were cultured under conditions known to be effective in arresting the growth of pontine mossy fibers (Baird et al., 1992a): granule neurons were plated at $7500 \mathrm{cells} / \mathrm{mm}^{2}$ and cultured in serum-free medium consisting of Eagle's basal medium with Earle's salts (Gibco) supplemented with $20 \mathrm{~mm}$ sodium bicarbonate, $2 \mathrm{mM}$ L-glutamine (Gibco), glucose (final concentration $32 \mathrm{mM}$ ), penicillin/streptomycin (Gibco, 20 J/ml each), $5 \mathrm{mg} / \mathrm{l}$ insulin- $5 \mathrm{mg} / \mathrm{l}$ transferrin-5 $\mu \mathrm{g} / \mathrm{ml}$ sodium selenite (Sigma), and 1\% bovine serum albumin, fraction V (Sigma). Cultures were incubated at $35.5^{\circ} \mathrm{C}$ in $5 \% \mathrm{CO}_{2}$.

After $24 \mathrm{hr}$, the medium was replaced with serum-free medium or serum-free medium containing 20 or $50 \mu \mathrm{M} \quad \mathrm{D}(-)$-2-amino-5phosphonopentanoic acid (D-AP5; Tocris Cookson, Bristol, UK), $10 \mu \mathrm{M}$ 6-cyano-7-nitroquinoxaline-2,3-dione (CNQX; Tocris Cookson), 20 or 50 $\mu \mathrm{M}$ NMDA (Sigma), or $50 \mu \mathrm{M}$ AMPA (Tocris Cookson). Explants measuring $\sim 200 \mu \mathrm{m}$ in diameter were dissected from the basilar pontine nuclei of newborn mice and plated on subconfluent granule neuron monolayers prepared $24 \mathrm{hr}$ earlier (Baird et al., 1992a,b).

Immunocytochemistry. After an additional $48 \mathrm{hr}$, the cocultures were

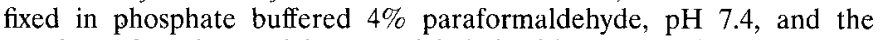
neurites of explant origin were labeled with a monoclonal antibody specific for mouse neurons, M6, using the indirect immunoperoxidase method (Baird et al., 1992a,b; Lund et al., 1986).

Quantitation of neurite outgrowth. The number of pontine neurites extending beyond $300 \mu \mathrm{m}$ from the center of their pontine explant of origin was determined using the Bioquant System IV for computerized morphometry (R \& M Biometrics, Nashville, TN) and a Zeiss microscope with phase-contrast optics (Thornwood, NY) (Baird et al., 1992a,b). In control conditions (explants on laminin in serum-free medium), there is a moderate amount of outgrowth extending beyond $300 \mu \mathrm{m}$, making this a practical distance for quantitation. Comparable results were obtained for 200 and $400 \mu \mathrm{m}$ (not shown). For measurements of NMDA-treated cultures and controls cultured in serum-free medium without NMDA, the number of pontine neurites extending beyond $200 \mu \mathrm{m}$ was determined. Two hundred micrometers was chosen, as opposed to the $300 \mu \mathrm{m}$ mark used for the experiments with antagonists in the present study, because few pontine neurites extended beyond $300 \mu \mathrm{m}$ on granule neurons when cultured in NMDA-containing medium.

Estimation of granule neuron survival. Companion culturc wclls from the same chamber slides prepared for the studies described above were used to assess granule neuron survival. As before, purified granule neurons were plated in serum-free medium, and after $1 \mathrm{~d}$ in vitro, the medium was replaced with control serum-free medium or medium containing glutamate receptor agonists or antagonists (NMDA, AMPA D-AP5, and CNQX). Granule neurons were fixed $3 \mathrm{~d}$ after plating in phosphate buffered $4 \%$ paraformaldehyde, $\mathrm{pH} 7.4$. Estimates of neuron survival were obtained by counting the number of process-bearing neurons in five predetermined areas near the center of each culture well, with each of the five areas measuring $14,400 \mu \mathrm{m}^{2}$. Measurements were made using the Bioquant System IV and a Leitz microscope (Leica, Deerfield, IL) equipped with phase-contrast optics.

\section{RESULTS}

\section{Effect of ionotropic glutamate antagonists on the stop-growing signal}

Explants of basilar pontine nuclei, a source of cerebellar mossy fibers (Brodal and Walberg, 1977; Burne et al., 1978), were cultured on granule neurons or on laminin. As in our previous studies (Baird ct al., 1992a,b), pontinc cxplants on laminin alone extended 100-300 neurites beyond $300 \mu \mathrm{m}$ from their centers, whereas on laminin with granule neurons, most pontine neurites terminated on granule neurons $<100 \mu \mathrm{m}$ from the edge of their explant of origin, resulting in a reduction in long $(>300 \mu \mathrm{m})$ neurites of $\sim 90 \%$ on average (Fig. 1A,D; Table 1). Pontine neurites extending on laminin grew in bundles of larger diameter than those extending on granule cells on laminin, where they appeared to extend as single fibers or in much smaller fascicles.
This indicates a greater tendency for pontine neurites to grow in fascicles on simple, defined substrates than on target granule neurons, which is consistent with previous comparisons of pontine neurite extension on polylysine, laminin, and granule neurons (Baird et al., 1992b).

We then tested whether NMDA receptors were involved in the stop-growing signal provided by granule neurons. NMDA or nonNMDA antagonists were added to granule cell cultures immediately before explants of pontine nuclei. Specific antagonists of NMDA or non-NMDA receptors were used: D-AP5 and CNQX, respectively. Among specific NMDA antagonists, D-AP5 was chosen because it is known to block currents gated by NMDA receptors in granule neurons, which have been extensively characterized (Garthwaite and Brodbelt, 1989; Silver et al., 1992; D'Angelo et al., 1993; Farrant ct al., 1994). Compared with control cultures grown in serum-free medium, in medium containing $20 \mu \mathrm{M}$ D-AP5, there was a fourfold increase in the number of long $(>300 \mu \mathrm{m})$ pontine neurites on granule neurons (Fig. $1 D, F$; Table 1). In the absence of granule neurons, addition of D-AP5-containing medium to pontine explants cultured on laminin resulted in no statistically significant $(p<0.05)$ change in outgrowth (Fig. 1A,C; Table 1). Therefore, D-AP5 does not act solely on the pontine neurites to increase their extension, but interferes with an interaction between granule neurons and pontine neurites that is required for the stop-growing signal. As with D-AP5, similar results were obtained with kynurenic acid ( $1 \mathrm{~mm})$, a general antagonist of both NMDA and non-NMDA ionotropic glutamate receptors (not shown). In contrast, the non-NMDA antagonist CNQX at $10 \mu \mathrm{M}$ had no effect on neurite outgrowth from pontine explants on laminin or on granule neurons on laminin (Table 1). Thus, functional NMDA receptors, but not non-NMDA receptors, are involved in the stop-growing signal.

\section{Effect of ionotropic glutamate agonists on the stop-growing signal}

To further investigate the specific involvement of NMDA receptors, we used the selective agonists of ionotropic glutamate receptors, AMPA and NMDA. AMPA $(50 \mu \mathrm{M})$, an agonist of nonNMDA receptors, did not affect pontine neurite extension on laminin, or extension on granule neurons on laminin compared with cultures without AMPA (Table 2). In cultures on laminin alone with or without AMPA, large numbers of pontine neurites extended beyond $300 \mu \mathrm{m}$ from the explant center. Similarly, the number of long neurites was dramatically reduced when pontine explants were cultured with or without AMPA on granule neurons on laminin. When the medium contained $20 \mu \mathrm{M}$ NMDA, however, three- to fourfold fewer long $(>200 \mu \mathrm{m})$ neurites extended from explants cultured on granule neurons, compared with similar cocultures in medium without NMDA, indicating an increase in stop-growing activity by NMDA (Fig. $1 D, E$; Table 2). In NMDAtreated cultures, very few pontine neurites were observed to extend beyond the edge of the explant, and those that did terminated on granule neurons usually within $50 \mu \mathrm{m}$ from the edge of the explant (Fig. $1 E$ ). The effectiveness of the stop-growing signal was further elevated by a higher concentration of NMDA $(50 \mu \mathrm{M})$, which decreased the number of long neurites by approximately sixfold compared with cocultures in medium without NMDA (Table 2). Both 20 and $50 \mu \mathrm{M}$ NMDA had relatively small, statistically insignificant $(p>0.05)$ effects on the extension of pontine neurites on laminin without granule neurons (Fig. 1A,B). Therefore, as suggested by the experiments with glutamate antagonists, these results with agonists indicate that NMDA-responsive 


\section{LAMININ}

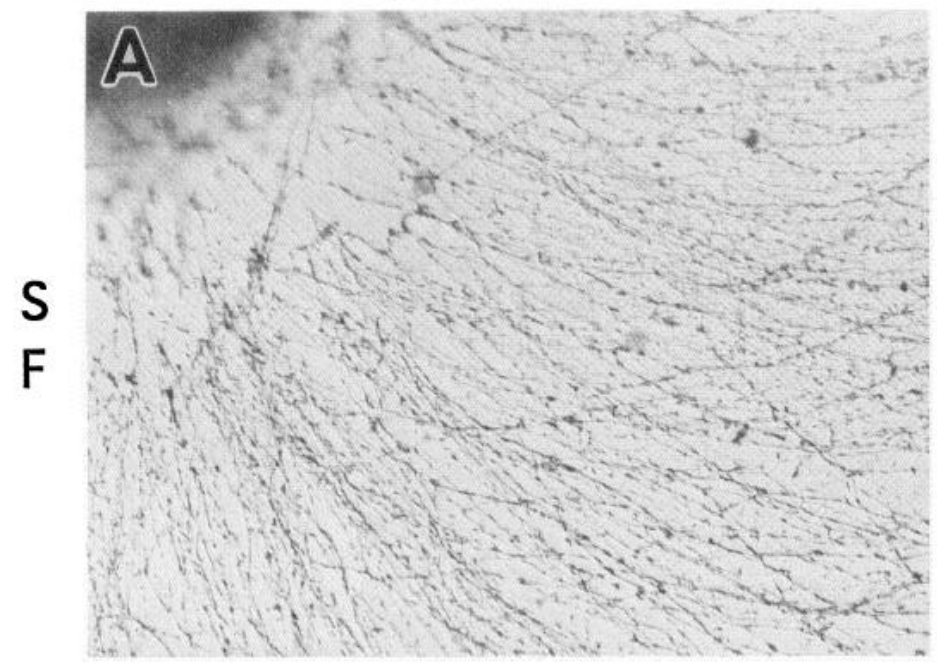

\section{GRANULE CELLS ON LAMININ}
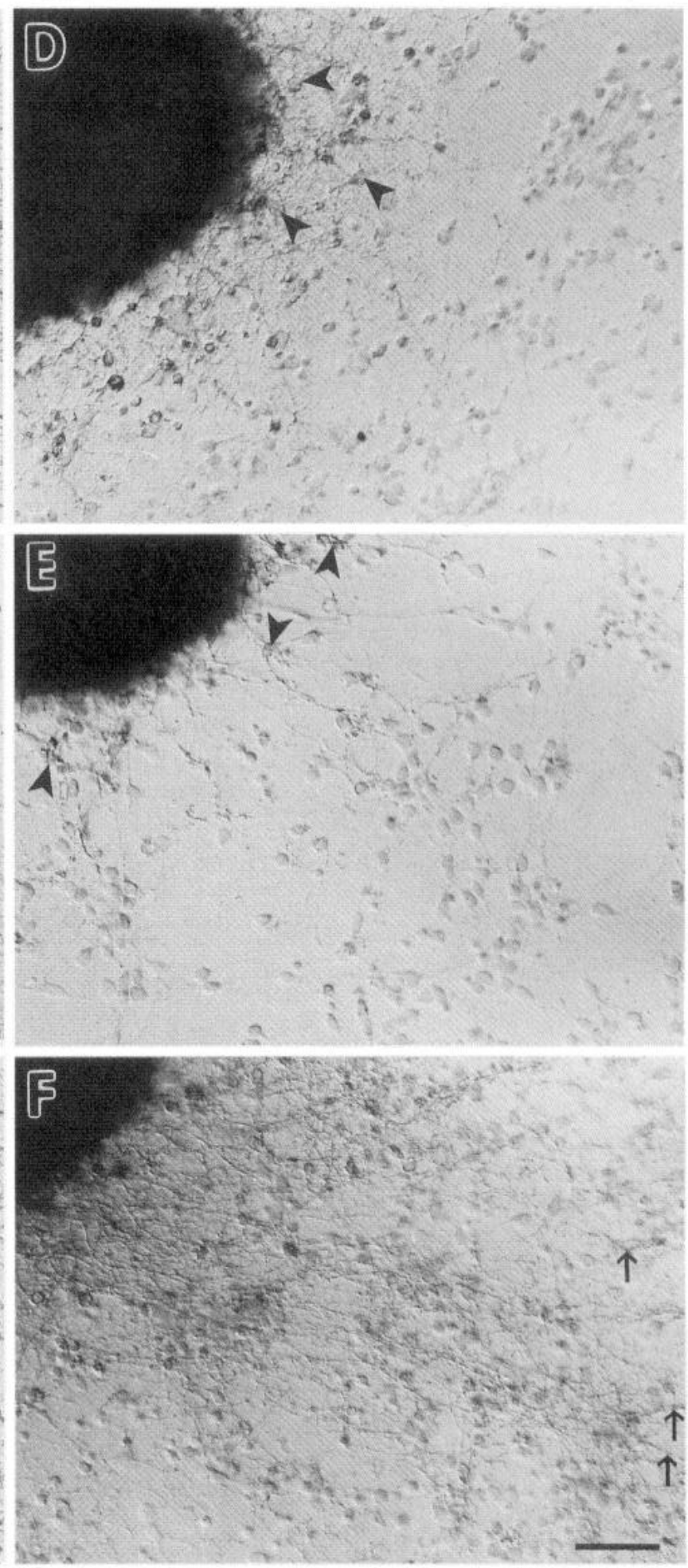

Figure 1. Neurite outgrowth from basilar pontine explants dissected from newborn mice and cultured for 48 hr. Panels on the left $(A-C)$ are controls with pontine explants cultured on laminin in the absence of granule neurons. Numbers of neurites are similar in each case, reaching lengths much $>250$ $\mu \mathrm{m} . A$, Serum-free $(S F)$ control medium; $B$, SF medium with $20 \mu \mathrm{M} N M D A ; C$, SF medium with $20 \mu \mathrm{M} D-A P 5$. $D$, Pontine explants cultured on granule neurons in SF medium. Most pontine neurites do not extend beyond granule cells (arrowheads) within $50 \mu \mathrm{m}$ from the edge of the explant. $E$, Pontine explants cultured on granule cells in SF medium with $20 \mu \mathrm{M}$ NMDA. Most pontine neurites do not extend beyond granule neurons (arrowheads) within $30 \mu \mathrm{m}$ from the edge of the explant. $F$, Pontine explants cultured on granule cells in SF medium with $20 \mu \mathrm{M}$ D-AP5. Abundant pontine neurite outgrowth extends beyond $200 \mu \mathrm{m}$ from the edge of the explant (arrows). Scale bar, $30 \mu \mathrm{m}(A-F)$. 


Table 1. Effect of ionotropic glutamate receptor antagonists on neurite outgrowth from explants of pontinc nuclei
\begin{tabular}{llll} 
Serum-free & $\begin{array}{l}\text { Pontine neurites on } \\
\text { medium (SF) }\end{array}$ & $\begin{array}{l}\text { Number of } \\
\text { explants }\end{array}$ & $\begin{array}{l}\text { Pontine neurites on } \\
\text { granule cells } \pm \text { SEM }^{\alpha}\end{array}$ \\
\hline Control & $100 \pm 11$ & 14 & $11 \pm 6.3$ \\
D-AP5 $(20 \mu \mathrm{M})$ & $91 \pm 12$ & 10 & $48 \pm 8.5^{b}$ \\
CNQX $(10 \mu \mathrm{M})$ & $108 \pm 9$ & 8 & $6.9 \pm 6.6$ \\
\hline
\end{tabular}

${ }^{a}$ Number of neurites that extended beyond $300 \mu \mathrm{m}$ on laminin in control medium is defined as $100 \%$.

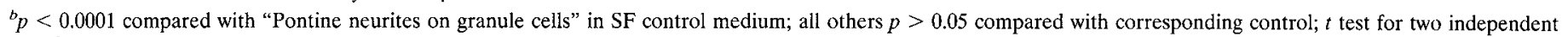
samples.

glutamate receptors are specifically involved in the stop-growing signal and affect an interaction between granule neurons and pontine neurites that mediates the stop-growing signal.

\section{Effect of glutamate agonists and antagonists on cell survival}

NMDA receptor activity is known to affect granule neuron survival under certain culture conditions (Gallo et al., 1987; Didier et al., 1990; Schramm et al., 1990; Bessho et al., 1994). To test whether glutamate receptor activity affects the stop-growing signal by altering granule neuron survival, the number of granule neurons that were able to elaborate processes after $3 \mathrm{~d}$ in culture in the absence of pontine explants was determined in control medium and in media containing a glutamate agonist or antagonist (20 and $50 \mu \mathrm{M}$ NMDA, $50 \mu \mathrm{M}$ AMPA, $50 \mu \mathrm{M}$ D-AP5, or $10 \mu \mathrm{M}$ CNQX). In control cultures in which the medium was replaced with serum-free medium after $1 \mathrm{~d}$ of culture in serum-free medium without agonist or antagonist, the mean density ( \pm SD) of process-bearing neurons was found to be $4000 \pm 630$ cells $/ \mathrm{mm}^{2}$ after $3 \mathrm{~d}$ of culture. When comparing control granule neurons cultured in serum-free medium with granule neurons cultured in serum-free medium containing agonists or antagonists, no significant difference $(p<0.10)$ in the number of process-bearing granule neurons was observed on day 3 when control medium had been replaced with control, agonist, or antagonist medium after 1 $\mathrm{d}$ (Table 3). A further indication that the agents tested did not affect neuron survival is that none of the agents had a statistically significant effect $(p<0.05)$ on neurite outgrowth when pontine explants were grown in the absence of target cells (Tables 1,2). If the survival of pontine neurons were changed, a corresponding change in the number of neurites extending from pontine explants would also be expected.

\section{DISCUSSION}

Our results indicate that NMDA receptor activity affects the arrest of pontine mossy fiber neurites by granule neurons, with NMDA enhancing, and its antagonist D-AP5, disrupting arrest.
None of the glutamate agonists or antagonists tested affected pontine neurite extension in the absence of granule neurons or the survival of the granule neurons themselves. These results have implications for the regulation of neurite extension by NMDA receptors during initial contacts between axons and target neurons, and during the later refinement of axon arbors.

\section{Molecular character of stop-growing signals}

The molecular mechanism by which target neurons interrupt the extension of afferent axons requires communication between target neuron and growth cone, which might be mediated by receptor-ligand binding. Neurotransmitters and their receptors are candidate molecules for this mechanism because they regulate neuronal motility, including neuronal migration (Komuro and Rakic, 1993) and axonal growth (Kater and Mills, 1991). In addition, neurotransmitters and their receptors are neuronspecific, which might allow target neurons to specifically regulate the growth of appropriate axons.

Neurotransmitters have been found to act in concert with other classes of molecules during the regulation of axonal growth, including adhesion molecules (Glanzman et al., 1990; Landmesser et al., 1990; Bailey et al., 1992; Mayford et al., 1992; Peter et al., 1994). Another stop-signal molecule, s-laminin, has been proposed to arrest the growth of motor axons when they arrive at future synaptic sites of the neuromuscular junction, based on its ability to inhibit the growth of axons in vitro (Porter et al., 1995). s-Laminin is also found in the CNS (Hunter et al., 1992) but has not been examined in the cerebellum (Sanes and Hunter, personal communication).

The stop-growing signal also might consist of a modulation of a neurite-promoting activity such as that offered by neurotrophins, including more recently identified factors in the CNS (Cohen et al., 1994; Gao et al., 1995; Segal et al., 1995). Evidence suggesting that neurotrophins could regulate mossy fiber growth includes brain-derived neurotrophic factor (BDNF) and NT-4/5 expression in the developing cerebellum (Maisonpierre et al., 1990;

Table 2. Effect of ionotropic glutamate receptor agonists on neurite outgrowth from explants of pontine nuclei

\begin{tabular}{|c|c|c|c|c|}
\hline $\begin{array}{l}\text { Serum-free } \\
\text { medium (SF) }\end{array}$ & $\begin{array}{l}\text { Pontine neurites on } \\
\text { laminin } \pm \mathrm{SEM}^{a}\end{array}$ & $\begin{array}{l}\text { Number of } \\
\text { explants }\end{array}$ & $\begin{array}{l}\text { Pontine neurites on } \\
\text { granule cells } \pm \mathrm{SEM}^{a}\end{array}$ & $\begin{array}{l}\text { Number of } \\
\text { explants }\end{array}$ \\
\hline Control & $100 \pm 8.8$ & 11 & $22 \pm 4.4$ & 14 \\
\hline AMPA $(50 \mu \mathrm{M}$ & $94 \pm 19$ & 9 & $17 \pm 6.3$ & 11 \\
\hline $\operatorname{NMDA}(20 \mu \mathrm{M})$ & $136 \pm 25$ & 10 & $5.4 \pm 2.0^{b}$ & 17 \\
\hline NMDA $(50 \mu \mathrm{M})$ & $94 \pm 22$ & 10 & $3.7 \pm 1.2^{b}$ & 12 \\
\hline
\end{tabular}

${ }^{a}$ The number of neurites that extended beyond $200 \mu \mathrm{m}$ on laminin in control medium is defined as $100 \%$, rather than $300 \mu \mathrm{m}$ as in Table 1 because of the small number of neurites extending beyond $300 \mu \mathrm{m}$ in NMDA-treated cultures of pontine neurites growing on granule neurons.

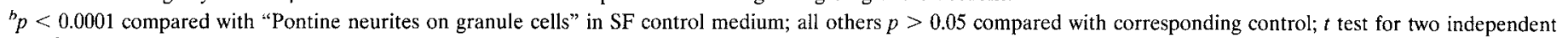
samples. 
Table 3. Effect of glutamate agonists and antagonists on granule neuron survival

\begin{tabular}{ll} 
Culture condition & $\begin{array}{l}\text { Process-bearing cells after } 3 \mathrm{~d} \\
(\% \text { control } \pm \mathrm{SD})\end{array}$ \\
\hline $20 \mu \mathrm{M}$ NMDA & $110 \pm 14^{a}$ \\
$50 \mu \mathrm{M}$ NMDA & $123 \pm 35^{a}$ \\
$50 \mu \mathrm{M}$ AMPA & $101 \pm 19^{a}$ \\
$50 \mu \mathrm{M}$ D-AP5 & $108 \pm 14^{a}$ \\
$10 \mu \mathrm{M}$ CNQX & $94 \pm 22^{a}$
\end{tabular}

${ }^{a} p>0.10$ compared with control cultures in serum-free medium without agonist or antagonist, $t$ test for two independent samples.

Rocamora et al., 1993; Timmusk et al., 1993), BDNF promotion of neurite outgrowth from pontine explants, and pontine expression of a BDNF and NT-4/5 receptor, trkB (Rabacchi et al., 1995).

Growth-cone collapsing factors might also participate in the stopgrowing signal. The first collapsing factor to be isolated was collapsin, a brain-derived membrane glycoprotein, which, like the stop-growing activity of granule neurons, does not act on retinal axons (Luo et al., 1993). In contrast to the action of collapsin, which collapses growthcone structure or induces turning of growth cones away from bound collapsin (Fan and Raper, 1995), pontine neurite extension is arrested by granule neurons often with the persistence of filopodia and lamellopodia (Baird et al., 1992b).

Neurotransmitters and other molecules involved in the stopgrowing signal would ultimately act on the cytoskeleton of mossy fiber growth cones to arrest their extension (Bentley and O'Connor, 1994). For example, binding of adhesion molecules during neurite extension over cellular substrates activates several second-messenger systems, including the influx of calcium (Williams ct al., 1993), which destabilizes the cytoskcleton (Lankford and Letourneau, 1991). Indeed, some of the effects of neurotransmitters on neurite extension have been attributed to changes in calcium levels in growth cones, with decreased growth-cone motility accompanying changes in calcium concentration away from an optimal level (Kater and Mills, 1991). Increases in cytosolic calcium concentration have been shown to mediate growth-cone collapse in some cases (Bandlow el al., 1993; Igarashi et al., 1993), but an exception has been identified (Ivins et al., 1991). It remains to be determined whether changes in growth-cone calcium levels accompany the stop-growing signal, but if so, such changes would depend on the presence of target granule neurons.

\section{NMDA receptor regulation of the stop-growing signal}

NMDA may regulate the stop-growing signal by binding to receptors on mossy fibers, granule neurons, or both, but the presence of functional NMDA receptors has only been established for granule neurons (Garthwaite and Brodbelt, 1989; Silver et al., 1992; D'Angelo et al., 1993; Farrant et al., 1994). NMDA receptor subunits 1, 2A, and $2 \mathrm{~B}$ are expressed, however, in the pontine nuclei of newborn rats (Akazawa et al., 1994). NMDA receptors on granulc ncurons might be dircctly activatcd by glutamate released from approaching mossy fiber growth cones, as has been described for acetylcholine, which is known to be released from extending motoneuron growth cones (Hume et al., 1983; Young and Poo, 1983). Subsequently, mossy fibers would then be induced to arrest their extension via a retrograde signal, such as nitric oxide or arachidonic acid, both known to be produced by granule neurons in response to NMDA receptor activalion (Lazarewicz et al., 1990; Garthwaite, 1991). Preliminary results, however, indi- cate that perturbing nitric oxide using inhibitors of nitric oxide synthase or by adding hemoglobin does not affect the stopgrowing signal (not shown).

Alternatively, NMDA may affect the stop-growing signal indirectly by acting on granule or pontine neurons. NMDA receptor activity in pontine neurons also might alter the ability of pontine growth cones to detect stop-growing signal molecules produced by granule neurons. Regulation of stop-growing signal molecules could occur via changes in gene expression after NMDA receptor activation, which is well documented (Didier et al., 1989; Szekely et al., 1990; Ghosh and Greenberg, 1995). Recent results indicate that paraformaldehyde-fixed (Baird and Kruk, 1994) and osmotically killed, as well as living-granule neurons, can provide a stop-growing signal, suggesting that the signal is a passively provided granule neuron surfacc or matrix molecule(s). These results suggest that the stop-growing signal does not require NMDA receptors, but that the amount or activity of the signal is regulated by NMDA receptor activity. Only in live neurons could NMDA receptor activity modulate the amount of such a molecule or its efficacy, perhaps via calcium activation of other second-messenger systems (Ghosh and Greenberg, 1995).

Although it is possible that NMDA and D-AP5 act on the stop-growing signal by affecting granule neuron survival and, in turn, the amount of granule neuron membrane, our results do not support this alternative. Under some culture conditions, high potassium (10-25 mM) or NMDA affects granule neuron survival (Gallo et al., 1987; Balázs et al., 1988; Didier et al., 1990) or neurite outgrowth (Pearce et al., 1987; Cambray-Deakin and Burgoyne, 1992). Conditions that enhanced the stop-growing signal ( $5 \mathrm{~mm}$ potassium and $20 \mu \mathrm{M}$ NMDA over a $2 \mathrm{~d}$ period), however, had no effect on granule neuron survival in our studies or in those of Balázs et al. (1988).

\section{NMDA receptors and the remodeling of axon arbors}

In addition to their effects on the stop-growing signal, NMDA receptors have been shown to be involved in the refinement of axon arbors. In the cerebellum, active NMDA receptors are required during the elimination of Inultiple-climbing fiber innervation of Purkinje cells (Rabacchi et al., 1992). In the tectum, lateral geniculate nuclei, visual cortex, and trigeminal nuclei, active NMDA receptors are required during the remodeling of exuberant branches and the focusing of arbors to specific territories, stages that are essential for the proper establishment of synaptic circuitry (Goodman and Shatz, 1993; Li et al., 1994). Recent work by O'Rourke et al. (1994) in which retinal growth cones were imaged in real time during arborization in tectum has shown that reduction in synaptic activity increased the net rate of extension and withdrawal of new branches. Our results indicate that when cerebellar cultures are treated for $48 \mathrm{hr}$ with NMDAantagonists, also presumably reducing synaptic activity, axons extend for longer distances over target cells. Perhaps a similar increase in growth-cone motility occurs in our cultures during axon extension in the presence of NMDA antagonists and contributes to the extension of longer axons. In addition, chronically decreasing the effectiveness of NMDA receptors in the frog tectum reduces the number of synaptic contacts formed by retinal axons (Yen et al., 1995). Whether the longer pontine axons we observed in D-AP5-treated cultures also form fewer synapses with granule neurons as predicted from the in vivo results with retinal axons remains to be determined.

Our results suggest that the NMDA receptor-dependent stages of axonal development ultimately involve the regulation of 
growth-cone advance by target cells either during initial contacts or later arborization, and thereby allow synaptic activity to shape both of these stages of development. NMDA receptors would not directly participate in the stop-growing signal but would serve to modulate its effector molecules, which are not yet identified. NMDA receptor activity is known to affect the form of axon arbors in several regions of the CNS, and in these cases, the stop-growing signal might be a link between changes in NMDA receptor activation and changes in the rate of neurite extension.

\section{REFERENCES}

Akazawa C, Shigemoto R, Bessho Y, Nakanishi S, Mizuno N (1994) Differential expression of five $N$-methyl-D-aspartate receptor subunit mRNAs in the cerebellum of developing and adult rats. J Comp Neurol 347:150-160.

Audinat E, Lambolez B, Rossier J, Crépel F (1994) Activity-dependent regulation of $N$-methyl-D-aspartate receptor subunit expression in rat cerebellar granule cells. Eur J Neurosci 6:1792-1800.

Bailey CH, Chen M, Keller F, Kandel ER (1992) Serotonin-mediated endocytosis of apCAM: an early step of learning related synaptic growth in Aplysia. Science 256:645-649.

Baird DH, Kruk B (1994) Arrest of axonal growth in vitro by living, sectioned or fixed target neurons. Soc Neurosci Abstr 20:1282.

Baird DH, Baptista CA, Wang L-C, Mason CA (1992a) Specificity of a target neuron-derived stop signal for afferent axonal growth. J Neurobiol 23:579-591.

Baird DH, Hatten ME, Mason CA (1992b) Cerebellar target neurons provide a stop-signal for afferent neurite extension. J Neurosci 12:619-634.

Balázs R, Jørgensen OS, Hack N (1988) $N$-methyl-D-aspartate promotes the survival of cerebellar granule cells in culture. Neuroscience 27:437-451.

Bandtlow CE, Schmidt MF, Hassinger TD, Schwab ME, Kater SB (1993) Role of intracellular calcium in NI-35-evoked collapse of neuronal growth cones. Science 259:80-83.

Bentley D, O'Connor TP (1994) Cytoskeletal events in growth cone steering. Curr Opin Neurobiol 4:43-48.

Bessho Y, Nawa H, Nakanishi S (1994) Selective up-regulation of an NMDA receptor subunit mRNA in cultured cerebellar granule cells by $\mathrm{K}(+)$-induced depolarization and NMDA treatment. Neuron 12:87-95.

Brodal P, Walberg F (1977) The pontine projection to the cerebellar anterior lobe. An experimental study in the cat with retrograde transport of horseradish peroxidase. Exp Brain Res 29:233-248.

Burne RA, Eriksson MA, Saint-Cyr JA, Woodward DJ (1978) The organization of the pontine projection to lateral cerebellar areas in the rat: dual zones in the pons. Brain Res 139:340-347.

Cambray-Deakin MA, Burgoyne RD (1992) Intracellular $\mathrm{Ca}^{2+}$ and $N$-methyl-D-aspartate-stimulated neuritogenesis in rat cerebellar granule cell cultures. Dev Brain Res 66:25-32.

Cohen A, Bray GM, Aguayo AJ (1994) Neurotrophin-4/5 (NT-4/5) increases adult rat retinal ganglion cell survival and neurite outgrowth in vitro. J Neurobiol 25:953-959.

D'Angelo E, Rossi P, Tagiletti V (1993) Different proportions of $N$-methyl-D-aspartate and non- $N$-methyl-v-aspartate receptor currents at the mossy fibre-granule cell synapse of developing rat cerebellum. Neuroscience 53:121-130.

Didier M, Roux P, Piechaczyk M, Verrier B, Bockaert J, Pin J-P (1989) Cerebellar granule cell survival and maturation induced by $\mathrm{K}^{+}$and NMDA correlate with c-fos proto-oncogene expression. Neurosci Lett 107:55-62.

Didier M, Heaulme M, Soubrié P, Bockaert J, Pin J-P (1990) Rapid, sensitive and simple method for quantification of both neurotoxic and neurotrophic effects of NMDA on cultured cerebellar granule cells. J Neurosci Res 27:25-35.

Fan J, Raper JA (1995) Localizcd collapsing cucs can steer growth cones without inducing their full collapse. Neuron 14:263-274.

Farrant M, Feldmeyer D, Takahashi T, Cull-Candy SG (1994) NMDAreceptor channel diversity in the developing cerebellum. Nature 368:335-339.

Gallo V, Kingsbury A, Balázs R, Jørgensen OS (1987) The role of depolarization in the survival and differentiation of cerebellar granule cells in culture. J Neurosci 7:2203-2213.
Gao W-Q, Zheng JL, Karihaloo M (1995) Neurotrophin-4/5 (NT-4/5) and brain-derived neurotrophic factor (BDNF) act at later stages of cerebellar granule cell differentiation. J Neurosci 15:2656-2667.

Garthwaite J (1991) Glutamate, nitric oxide and cell-cell signaling in the nervous system. Trends Neurosci 14:60-67.

Garthwaite J, Brodbelt AR (1989) Synaptic activation of $N$-methyl-Daspartate and non- $N$-methyl-D-aspartate leceptors in the mossy fibre pathway in adult and immature rat cerebellar slices. Neuroscience 26:401-412.

Ghosh A, Greenberg ME (1995) Calcium signaling in neurons: molecular mechanisms and cellular consequences. Science 268:239-247.

Glanzman DL, Kandel ER, Schacher S (1990) Target-dependent structural changes accompany long-term synaptic facilitation in Aplysia neurons. Science 249:799-802.

Goodman CS, Shatz CJ (1993) Developmental mechanisms that generate precise patterns of neuronal connectivity. Cell 72:77-98.

Hume RI, Role LW, Fischbach GD (1983) Acetylcholine release from growth cones detcctcd with patchcs of acetylcholine receptor-rich membranes. Nature 305:632-634.

Hunter DD, Llinas R, Ard M, Merlie JP, Sanes JR (1992) Expression of s-laminin and laminin in the developing rat central nervous system. J Comp Neurol 323:238-251.

Igarashi M, Strittmatter SM, Vartanian T, Fishman MC (1993) Mediation by $\mathrm{G}$ proteins of signals that cause collapse of growth cones. Science 259:77-79.

Ivins JK, Raper JA, Pittman RN (1991) Intracellular calcium levels do not change during contact-mediated collapse of chick DRG growth cone structure. J Ncurosci 11:1597-1608.

Kater SB, Mills LR (1991) Regulation of growth cone behavior by calcium. J Neurosci 11:891-899.

Komuro H, Rakic P (1993) Modulation of neuronal migration by NMDA recepturs. Science 260:95-97.

Landmesser L, Dahm L, Tang J, Rutishauser U (1990) Polysialic acid as a regulator of intramuscular nerve branching during embryonic development. Neuron 4:655-667.

Lankford KL, Letourneau PC (1991) Roles of actin filaments and three second-messenger systems in short-term regulation of chick dorsal root ganglion neurite outgrowth. Cell Motil Cytoskeleton 20:7-29.

Lazarewicz JW, Wroblewski JT, Costa E (1990) N-methyl-D-aspartatesensitive glutamate receptors induce calcium-mediated arachidonic acid release in primary cultures of cerebellar granule cells. J Neurochem 55:1875-1881.

Li Y, Erzurumlu RS, Chen C, Jhaveri S, Tonegawa S (1994) Whiskerrelated neuronal patterns fail to develop in the trigeminal brainstem nuclei of NMDAR1 knockout mice. Cell 76:427-437.

Lund RD, Perry VH, Lagenaur CF (1986) Cell surface changes in the developing optic nerve of mice. J Comp Neurol 247:439-446.

Luo Y, Raible D, Raper JA (1993) Collapsin: a protein in brain that induces the collapse and paralysis of neuronal growth cones. Cell $75: 217-227$

Maisonpierre PE, Belluscio L, Friedman B, Alderson RF, Wiegand SJ Furth ME, Lindsay RM, Yancopuolos GD (1990) NT-3, BDNF and NGF in the developing rat nervous system: parallel as well as reciprocal patterns of expression. Neuron 5:501-509.

Mason CA, Gregory E (1984) Postnatal maturation of cerebellar mossy and climbing fibers: transient expression of dual features on single axons. J Neurosci 4:1715-1735.

Mayer ML, MacDermott AB, Westbrook GL, Smith SJ, Barker JL (1987) Agonist- and voltage-gated calcium entry in cultured mouse spinal cord neurons under voltage clamp measured using arsenazo III. J Neurosci 7:3230-3244.

Mayford M, Barzilai A, Keller F, Schacher S, Kandel ER (1992) Modulation of an NCAM-related adhesion molecule with long-term synaptic plasticity in Aplysia. Science 256:638-644.

Moyner H, Burnashev N, Laurie DJ, Sakmann B, Seeburg PH (1994) Developmental and regional expression in the rat brain and functional properties of four NMDA receptors. Neuron 12:529-540.

O'Rourke NA, Cline IIT, Fraser SE (1994) Rapid remodeling of retinal arbors in the tectum with and without blockade of synaptic transmission. Neuron 12:921-934.

Palay SL, Chan-Palay V (1974) Cerebellar cortex: cytology and organization. New York: Springer.

Pearce IA, Cambray-Deakin MA, Burgoyne RD (1987) Glutamate acting on NMDA receptors stimulates neurite outgrowth from cerebellar granule cells. FEBS Lett 223:143-147. 
Peter N, Aronoff B, Wu F, Schacher S (1994) Decrease in growth coneneurite fasciculation by sensory or motor cells in vitro accompanies down regulation of Aplysia cell adhesion molecules by neurotransmitters. J Neurosci 14:1413-1421.

Porter BE, Weis J, Sanes JR (1995) A motoneuron-selective stop signal in the synaptic protein s-laminin. Neuron 14:549-559.

Rabacchi S, Bailly Y, Delhaye-Bouchaud N, Mariani J (1992) Involvement of the $N$-methyl-D-aspartate receptor in synapse elimination during cerebellar development. Science 256:1823-1825.

Rabacchi SA, Meyer SL, Baird DH, Springer JE (1995) The neurotrophic actions of BDNF in the developing pontine-cerebellar system. Soc Neurosci Abstr 21:1058.

Rocamora N, Garcia-Ladona FJ, Palacos JM, Mengod G (1993) Differential expression of brain-derived neurotrophic factor, neurotrophin-3, and low-affinity nerve growth factor receptor during the postnatal development of the rat cerebellar system. Mol Brain Res 17:1-8.

Schramm M, Eimerl S, Costa E (1990) Serum and depolarizing agents cause acute neurotoxicity in cultured cerebellar granule cells: role of the glutamate receptor responsive to $N$-methyl-D-aspartate. Proc Natl Acad Sci USA 87:1193-1197.

Segal RA, Pomeroy SL, Stiles CD (1995) Axonal growth and fasciculation linked to differential expression of BDNF and NT3 receptors in developing cerebellar granule cells. J Neurosci 15:4970-4981.
Silver RA, Traynelis SF, Cull-Candy SG (1992) Rapid-time-course miniature and evoked excitatory currents at cerebellar synapses in situ. Nature 355:163-166.

Szekely AM, Costa E, Grayson DR (1990) Transcriptional program coordination by $N$-methyl-D-aspartate-sensitive glutamate receptor stimulation in primary cultures of cerebellar neurons. Molec Pharm 38:624-633.

Timmusk T, Belluardo N, Metsis M, Persson H (1993) Widespread and developmentally regulated expression of neurotrophin-4 mRNA in rat brain and peripheral tissues. Eur J Neurosci 5:605-613.

Williams EJ, Doherty P, Turner G, Reid RA, Hcmperly JJ, Walsh FS (1993) Calcium influx into neurons can solely account for cell contactdependent neurite outgrowth stimulated by transfected L1. J Cell Biol 119:885-892.

Yamagata M, Sanes JR (1995) Lamina-specific cues guide outgrowth and arborization of retinal axons in the optic tectum. Development 121:189-200.

Yen L, Sibley JT, Constantine-Paton M (1995) Analysis of synaptic distribution within single retinal axonal arbors after chronic NMDA treatment. J Neurosci 15:4712-4725.

Young SH, Poo MM (1983) Spontaneous release of transmitter from growth cones of embryonic neurons. Nature 305:634-636. 